\title{
3 Pivotal long-term studies
}

Even the greatest nonsense purported is frequently justified by the fact that there was a study on it. In the field of nutrition alone, approximately 9000 articles are published in the medical literature worldwide every year - that is close to one "study" per hour. Reference to such nutritional studies therefore does not necessarily pack that much weight, especially when obviously backed by an interest group from industry. In contrast, the results from recognized research groups working at renowned universities or institutes published in specialized journals with high impact factors are much more compelling (Appendix). Here, the large-scale, international interventional and monitoring trials enrolling tens of thousands of volunteers and lasting many years should be given particular emphasis (- Tab. 3.1). Even their findings cannot automatically be assigned the conclusiveness given to laws of Nature, but they do constantly and reliably improve our knowledge about the many details of the physiological interconnections between diet, exercise and health. These form the basis of the content of the following chapters.

Among others, one of the most scientifically sound pieces of research is the Framingham Heart Study. On April 12, 1945, President Franklin D. Roosevelt died unexpectedly of a stroke. This event triggered the worldwide-longest, still ongoing study of cardiovascular disease. The town of Framingham with its 28,000 inhabitants in the area of Boston Massachusetts was chosen as the study site. The town's inhabitants were regarded as representing the perfect cross-section of the American population. This study is now investigating the third generation, usually comprising around 5000 test subjects.

\begin{tabular}{|c|c|c|}
\hline Study & $\begin{array}{l}\text { Ongoing } \\
\text { since }\end{array}$ & $\begin{array}{l}\text { Number } \\
\text { of subjects }\end{array}$ \\
\hline $\begin{array}{l}\text { Black Women's Health } \\
\text { Study }\end{array}$ & 1995 & 59,000 \\
\hline $\begin{array}{l}\text { California Teachers } \\
\text { Study }\end{array}$ & 1995 & 133,400 \\
\hline $\begin{array}{l}\text { Cancer Prevention } \\
\text { Study }\end{array}$ & $\begin{array}{l}1960 \text { (to } \\
1972 \text { ) }\end{array}$ & 1 million \\
\hline $\begin{array}{l}\text { Cancer Prevention } \\
\text { Study II }\end{array}$ & 1982 & 1.2 millions \\
\hline $\begin{array}{l}\text { Cancer Prevention } \\
\text { Study III }\end{array}$ & 2010 & 500,000 \\
\hline EPIC Study & 1992 & 519,000 \\
\hline $\begin{array}{l}\text { Framingham Heart } \\
\text { Study }\end{array}$ & 1948 & 5000 \\
\hline $\begin{array}{l}\text { Health Professionals } \\
\text { Follow-up Study }\end{array}$ & 1986 & 51,500 \\
\hline Interheart Study & 1997 & 30,000 \\
\hline $\begin{array}{l}\text { NIH-AARP Diet and } \\
\text { Health Study }\end{array}$ & 1995 & 567,000 \\
\hline Nurses' Health Study I & 1976 & 122,000 \\
\hline Nurses' Health Study II & 1989 & 116,500 \\
\hline Procam Study & 1978 & 50,000 \\
\hline Whitehall II Study & 1985 & 10,300 \\
\hline $\begin{array}{l}\text { Women's Health } \\
\text { Initiative }\end{array}$ & 1991 & 161,800 \\
\hline
\end{tabular}

